\title{
CAP-T cell expression system: a novel rapid and versatile human cell expression system for fast and high yield transient protein expression
}

\author{
Jens Wölfel", Ruth Essers, Corinna Bialek, Sabine Hertel, Nadine Scholz-Neumann, Gudrun Schiedner \\ From 22nd European Society for Animal Cell Technology (ESACT) Meeting on Cell Based Technologies \\ Vienna, Austria. 15-18 May 2011
}

\begin{abstract}
Backround
CAP (CEVEC's Amniocyte Production) cells are an immortalized cell line based on primary human amniocytes. They were generated by transfection of these primary cells with a vector containing the functions E1 and pIX of adenovirus 5. CAP cells allow for competitive stable production of recombinant proteins with excellent biologic activity and therapeutic efficacy as a result of authentic human posttranslational modification. In order to gain access to the benefits of the CAP technology also for early research, target evaluation or assay development, the transient expression system CAP-T was developed. CAP-T cells are based on the original CAP cells and additionally express the large $\mathrm{T}$ antigen of simian virus 40 (SV40).
\end{abstract}

\section{Results}

To characterize the CAP-T expression system, they were transiently transfected with an expression plasmid for the highly complex and glycosylated human $\alpha 1$-Antitrypsin (hAAT). This resulted in remarkably high expression levels of up to $60 \mathrm{mg} / \mathrm{L}$. These levels could be even increased 2.5 fold by adding an SV40 origin of replication (SV40ori) to the expression vector (Figure 1). When compared to HEK293T cells, CAP cells showed a significantly higher expression titer than HEK293T cells (data not shown). In order to understand these phenomena, the copy number of the expression plasmid, upon transfection, was determined. CAP-T efficiently replicated the expression plasmid containing the SV40ori, resulting in increasing copy numbers per cell over time yielding in about 4 times higher copy numbers than in HEK293T cells transfected with the same plasmid and in CAP-T cells transfected with the plasmid lacking the SV40ori (data not shown) and consequently in higher expression levels. In order to establish a more scalable transfection method than nucleofection, the suitability of different transfection reagents for the transfection of CAP-T cells was determined. In these experiments beside nucleofection, 293fectin and polyethylenimin (PEI) based transfection methods showed best results in small scale transfections, enabling the scalability of the transient transfection in CAP-T cells (data not shown). With the PEI based transfection method hAAT could be produced also in $300 \mathrm{~mL}$ shaking culture and $1 \mathrm{~L}$ bioreactor with product titers of up to $180 \mathrm{mg} / \mathrm{L}$ in simple batch processes of up to 10 days (data not shown). Several other glycosylated proteins have been tested in transient transfections of CAP-T cells yielding comparable product titers (Table 1 ).

\section{Summary}

In summary, CAP-T cells present a highly efficient transient expression system enabling the generation of $\mathrm{mg}$ amounts of the protein of interest for early research and development within only two weeks from gene to product. Furthermore, CAP-T cell produced proteins showed fully human posttranslational modification pattern, which was also observed for the original human CAP cells, the CAP-T cells were derived from. The CAP technology based on CAP-T cells for transient transfection and CAP cells for stable protein production [1] therefore provides a unique system in which the whole process from early research to production of therapeutic proteins can be run through with the same cell type.

CEVEC Pharmaceuticals GmbH, Cologne, Germany 


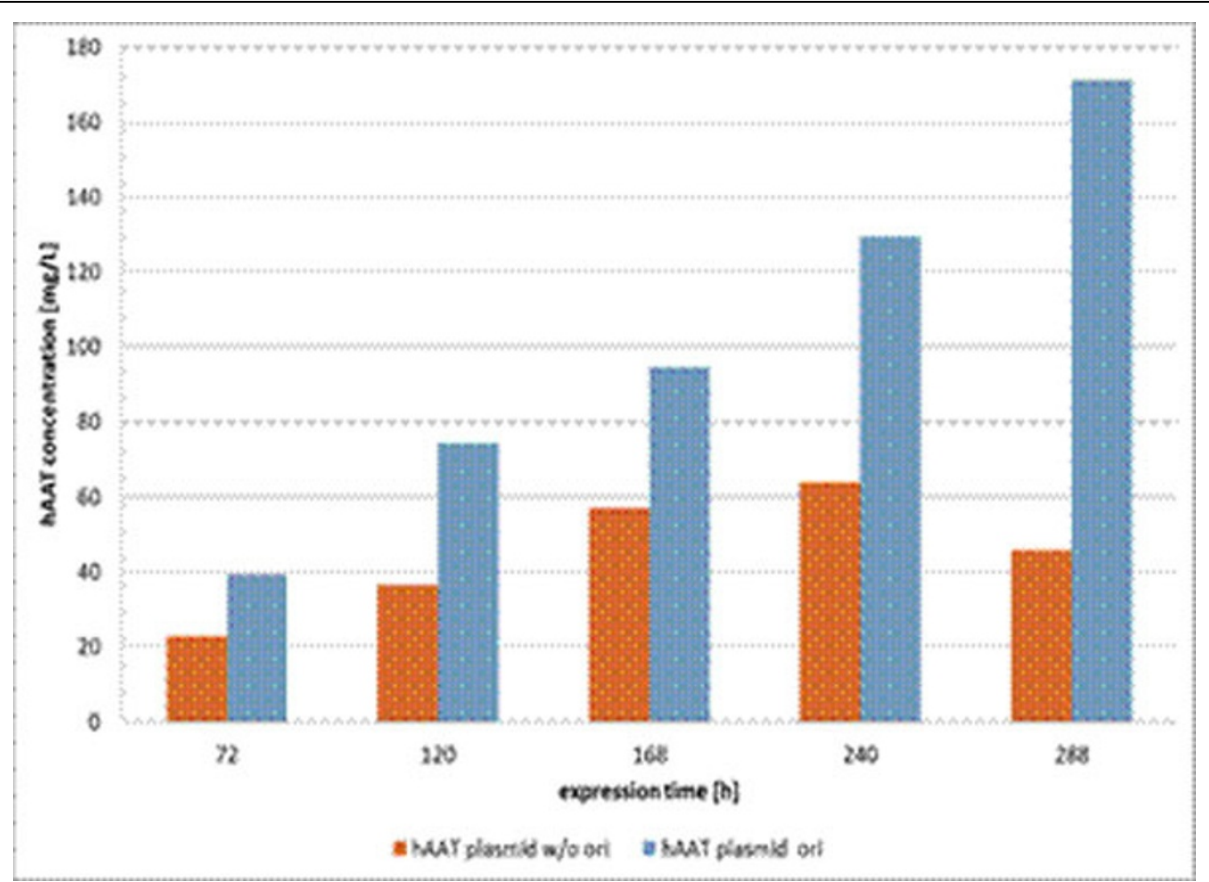

Figure 1 Transient expression of hAAT in CAP-T: Two plasmids containing a hAAt expression cassette were transfected by nucleofection $\left(1 \times 10^{7}\right.$ cells). The plasmid containing a SV40ori (ori) yielded about 2.5 time higher expression levels at maximum product concentration than a plasmid lacking this ori (w/o ori).

Table 1 Table 1 summarizes the relevant data from transient transfections of CAP-T cells in different scales with plasmids coding for different proteins of interest (hAAT, erythropoietin (EPO), C1-Inhibitor and IgG). Cells were either transfected by nucleofection $\left(1 \times 10^{7}\right.$ cells) or by PEI $\left(1.7 \times 10^{9}\right.$ cells $)$.

\begin{tabular}{|c|c|c|c|c|c|}
\hline & \multicolumn{2}{|c|}{ hAAT } & $\mathrm{EPO}$ & C1-Inhibitor & $\lg G$ \\
\hline cells transfected & $1 \times 10^{7}$ & $1.7 \times 10^{9}$ & $1 \times 10^{7}$ & $1 \times 10^{7}$ & $1 \times 10^{7}$ \\
\hline culture volume [ml] & 30 & 1000 & 60 & 30 & 30 \\
\hline culture time [days] & 9 & 6 & 10 & 12 & 6 \\
\hline viability at harvest [\%] & 85 & 70 & 80 & 87 & 80 \\
\hline volumetric productivity [mg/L] & 170 & 180 & 38 & 35 & 150 \\
\hline
\end{tabular}

\section{Reference}

1. Essers $R$, Kewes $H$, Schiedner $S$ : Improving volumetric productivity of a stable human CAP cell line by bioprocess optimization. BMC Proceedings, abstract within the same supplement.

doi:10.1186/1753-6561-5-S8-P133

Cite this article as: Wölfel et al:: CAP-T cell expression system: a novel rapid and versatile human cell expression system for fast and high yield transient protein expression. BMC Proceedings 2011 5(Suppl 8):P133.

Submit your next manuscript to BioMed Central and take full advantage of:

- Convenient online submission

- Thorough peer review

- No space constraints or color figure charges

- Immediate publication on acceptance

- Inclusion in PubMed, CAS, Scopus and Google Scholar

- Research which is freely available for redistribution 